\title{
Inhibin and activin in embryonic and fetal development in ruminants
}

\author{
G. Jenkin ${ }^{1,2}$, J. McFarlane ${ }^{2}$ and D. M. de Kretser ${ }^{2}$ \\ ${ }^{1}$ Department of Physiology and ${ }^{2}$ Institute of Reproduction and Development, Monash University, \\ Clayton, Victoria, Australia, 3168
}

Inhibin, activin and follistatin are protein hormones with diverse physiological roles. The involvement of inhibin in the regulation of pituitary $\mathrm{FSH}$ production and secretion in adult males and non-pregnant females is well established. However, it is unlikely that inhibin plays a similar role in pregnancy in ruminants. Inhibin and activin molecules show a high degree of structural similarity to potent growth and differentiation factors of the transforming growth factor $\beta$ (TGF- $\beta$ ) superfamily of peptides and their localization in a range of embryonic and fetal tissues indicates that they may thus play a role in development. Furthermore, the demonstration that follistatin is also present in a number of embryonic and fetal tissues and fluids has further implications for the actions of activin to which it binds. The role of inhibin, activin and follistatin in early development has yet to be established since gene knockout experiments have so far proved inconclusive. During mid- and late gestation, high concentrations of inhibin are found in the testes and plasma of male fetuses of sheep and cattle. Inhibin may play a role in regulating pituitary FSH release in late pregnancy, but the very high concentrations of this hormone in ovine fetal testes and in male fetal plasma compared with that observed in the fetal ovary and female fetal plasma has yet to be explained. The recent observation of high concentrations of inhibin, activin and follistatin in amniotic fluid surrounding the fetus is intriguing. Excretion via urine or lung liquid is partly responsible for the presence of these proteins in amniotic fluid. The fetal membranes and the placenta are also possible sources. It remains to be established whether these proteins constitute an inactive pool of secreted hormone or whether they have other actions in this fetal compartment.

\section{Introduction}

Inhibin was first isolated from bovine and porcine follicular fluid by Ling et al. (1985) and Robertson et al. (1985). Two isoforms of inhibin have been identified, inhibin $A$ and inhibin $B$. These glycoproteins can suppress FSH production and secretion from rat anterior pituitary cells in culture. They are formed by dimerization of a common $\alpha$ subunit, derived from a pro $\alpha$-c precursor molecule, and distinct $\beta$ subunits termed $\beta_{A}$ (inhibin $A$ ) and $\beta_{B}$ (inhibin $B$ ). Both $\beta_{A}$ and $\beta_{B}$ subunits, as well as the $\alpha$ subunit, have been identified in most species studied, but it appears that only the $\alpha$ and $\beta_{\mathrm{A}}$ subunits are significantly expressed in adult ruminants since neither the $\beta_{\mathrm{B}}$ subunit sequence nor the cDNA clone has been identified in sheep or cattle (see Tilbrook et al, 1992). The $\beta$ subunits of inhibin also form disulfide linked dimers. These proteins, which have the capacity to stimulate FSH production and decrease inhibin biopotency (Robertson et al, 1988), have been designated activin $A\left(\beta_{A} \beta_{A}\right)$, activin $B\left(\beta_{B} \beta_{B}\right)$ and activin $\mathrm{AB}\left(\beta_{\mathrm{A}} \beta_{B}\right)$. 


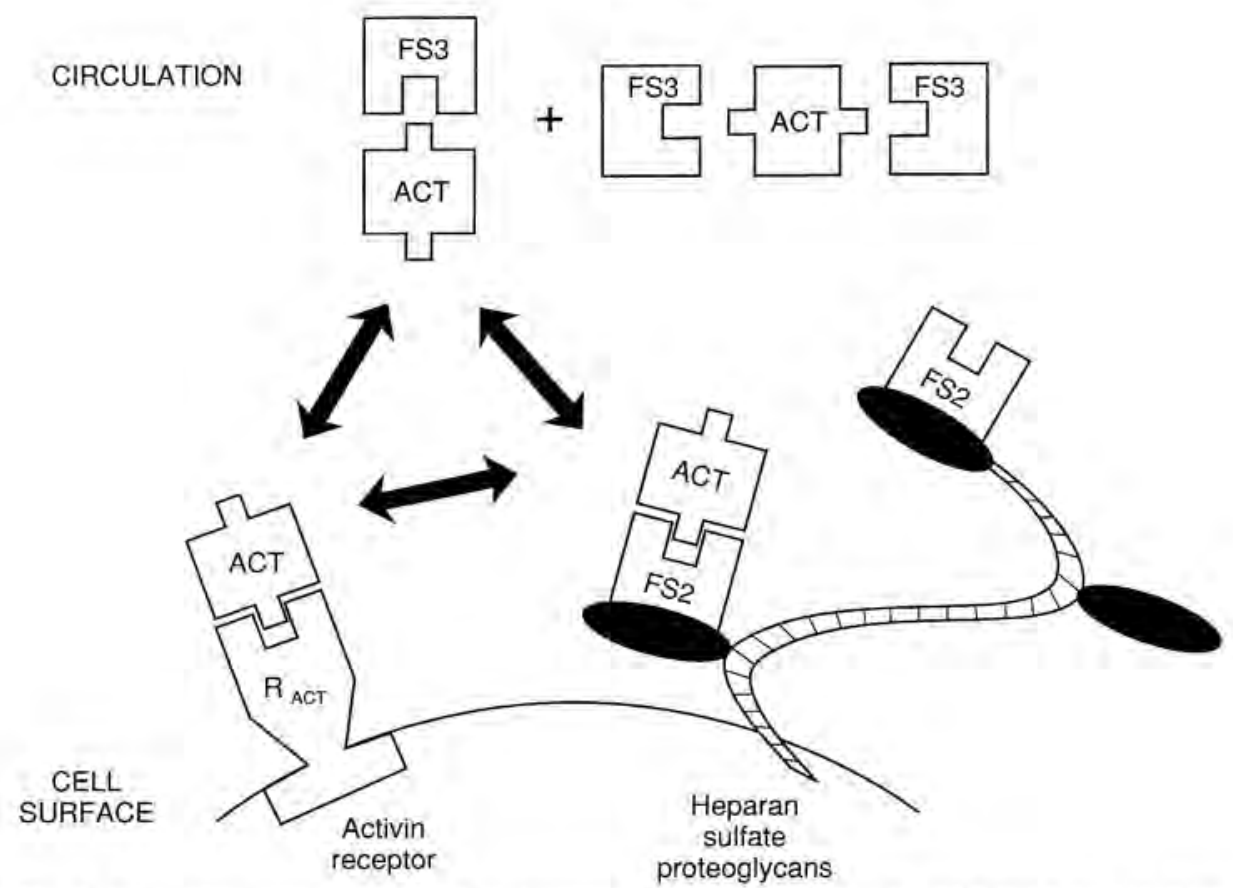

Fig. 1. Schematic representation of the interaction between activin (ACT) and follistatin (FS3). ACT can bind circulating FS3 in a $1: 2$ ratio. The major circulating forms of follistatin are FS303 and FS315. Activin also binds to cell surface receptors $\left(R_{A C T}\right)$ either directly or via association with follistatin 288 (FS2) which is bound to cell surface heparan sulfate proteoglycans.

A protein, initially co-purified from follicular fluid but structurally distinct from the inhibins and activins, was subsequently identified as follicle stimulating hormone-suppressing protein (FSP) or follistatin by Robertson et al. (1987) and Ueno et al. (1987). This protein can suppress FSH production by rat anterior pituitary cells in culture with a potency of 10-30\% that of the inhibins (Robertson et al., 1990; De Paolo et al., 1991). Although coded by a single gene, follistatin is now known to exist as several different isoforms arising from two precursor molecules generated by alternative splicing, together with different degrees of glycosylation (Michel et al., 1993). At least three major isoforms of follistatin are thought to exist, all of which have been demonstrated by Nakamura et al. (1990) to bind activin with a $K_{\mathrm{d}}$ value of approximately $\mathrm{I}$ nmol $\mathrm{I}^{-1}$. It has subsequently been revealed that activin has two binding sites for follistatin but that inhibin has only one binding site for follistatin. Since follistatin has only one binding site for activin and inhibin, it is likely that follistatin binds to these two proteins via their $\beta$ subunits (Shimonaka et al., 1991). The binding of activin to follistatin provides a potential role for this protein in neutralizing the bioactivity of circulating activin, as the $K_{d}$ value for the binding of activin to its own receptor is reported to be approximately $0.1 \mathrm{nmol} \mathrm{l}^{-1}$ (Matthews and Vale, 1991; Attisano et al, 1992). Furthermore, the presence of different isoforms of follistatin, all with the potential to bind activin, may be important in regulating the many actions of activin. Two full length core proteins, FS315 and FS303, containing 315 and 303 amino acids, respectively, constitute the circulating forms of follistatin, while a further carboxy-terminal truncated form containing 288 amino acids (FS 288) is not secreted but remains within the cell bound to cell surface heparan sulfate proteoglycans. Nakamura et al. (1991) proposed that, although circulating follistatin may neutralize the activity of activin, cell-bound follistatin could capture activin in the heparan sulfate proteoglycan matrix thus creating a reservoir of activin which potentially has the ability to control activin availability to its receptor (Fig. I).

Initial studies on the role of inhibin, activin and follistatin have focused on their potential feedback regulatory role on the pituitary secretion of FSH in adults (de Kretser and Robertson, 1989). Subsequent studies have demonstrated that they possess diverse paracrine and autocrine biological roles and often 
act as mutual antagonists. Thus, it has become recognized that these proteins have potent local regulatory functions in adult gonads (see Findlay, 1993) and possibly within the pituitary itself (Bilezikjian et al, 1993). The identification of these proteins in embryonic and fetal tissues and their potential roles in the fetus is the subject of this review.

\section{Feedback Role of Inhibin in Pregnant Ewes}

The classical feedback role of inhibin and steroids on pituitary production and secretion in adults is discussed in detail elsewhere (A. J. Tilbrook and I. J. Clarke) in this supplement. Although steroids act at the hypothalamus and the pituitary to inhibit $\mathrm{GnRH}$ and gonadotrophin synthesis and secretion respectively, inhibin, produced by granulosa cells in the female or Sertoli cells in the male, is thought to act solely at the anterior pituitary to inhibit FSH production and secretion preferentially (Tilbrook et al., 1993) thus leading to an inverse relationship between FSH and inhibin.

During pregnancy in ewes, the relationship between FSH and inhibin is altered. Plasma gonadotrophin concentrations ( $\mathrm{LH}$ and FSH) decrease to a nadir in late gestation (Chamley et al., 1974a; Jenkin et al., 1977). Furthermore, the release of LH and FSH in response to the administration of gonadotrophin releasing hormone $(\mathrm{GnRH})$ is suppressed to minimal values in late gestation (Chamley et al,, 1974a,b; Jenkin and Heap, 1974; Jenkin et al., 1977), while the release of prolactin in response to thyrotrophin releasing hormone is increased (Wright et al., 1981). In contrast to the cycle, this suppression of gonadotrophin release is not associated with high plasma concentrations of inhibin, as Findlay et al. (1991) demonstrated that immunoreactive inhibin concentrations decline from values equivalent to those observed during the cycle from day 40 of gestation to barely detectable concentrations by late gestation. It would appear that the combined chronic negative feedback effect of oestradiol and progesterone, and not inhibin, is responsible for the redirection of the synthetic and secretory function of the anterior pituitary away from gonadotrophins in favour of prolactin (Jenkin 1975; Chamley et al., 1976; Jenkin et al., 1977; Wright et al., 1978; see Fig. 2). A consequence of this redirection is that the surge of secretion of oestradiol associated with parturition (Challis, 1971) does not elicit the release of pituitary LH at this time.

\section{Embryonic Growth and Development}

Despite the low concentrations of circulating inhibin in maternal plasma during gestation in sheep and rats (Taya et al., 1989; Findlay et al., 1991; Yohkaichiya et al., 1991), there is increasing interest in the possible roles of these proteins in embryonic and fetal growth and development. The cloning of inhibin and activin in the late 1980s (Mason et al., 1985; Forage et al., 1986) led to the observation that their subunits, particularly the $\beta$ subunits, have a high degree of similarity to a range of growth and differentiation factors grouped together as the transforming growth factor (TGF) superfamily (Massagué, 1990). This similarity is particularly apparent in the carboxy-terminal amino acid sequence of the precursor polypepetide, as noted by the conservation and position of the cysteine residues. Members of the TGF $\beta$ superfamily include four structurally related subfamilies which all exert growth and differentiation regulatory activity: the TGF- $\beta$ family, the inhibin family, the decapentaplegic gene complex/VGI family and the Müllerian inhibiting substance family.

One of the first demonstrations that indicated that inhibin and activin may be regulators of early embryonic development was the observation that activin $A$ is a potent dorsal mesoderm inducing factor in animal cap explants from Xenopus and that activin has been isolated from Xenopus cells. Mesoderm induction is thought to be an initial step in early embryonic development. The early induction of mesodermal muscle cell types by activin, as well as notochord and neuro-ectodermal cells such as neuronal cells and melanocytes, provides strong evidence for a role of this protein in early embryonic development (for review see Huylebroeck et al., 1993). A similar role for activin has been reported in chicken embryos where it can induce formation of axial structures (Mitrani et al., 1990).

Subsequent studies in rats have demonstrated that inhibin, activin and follistatin, as well as the activin-IIB receptor, are expressed in a range of embryonic and fetal tissues and localization is consistent with growth effects during embryogenesis. The $\alpha$ subunit of inhibin has been identified in somites as early as day $10-12$ of pregnancy, while the $\beta$ subunit is present in heart primordium, decidua capsularis and uterine blood vessel endothelium. The activin-IIB receptor is widely distributed 


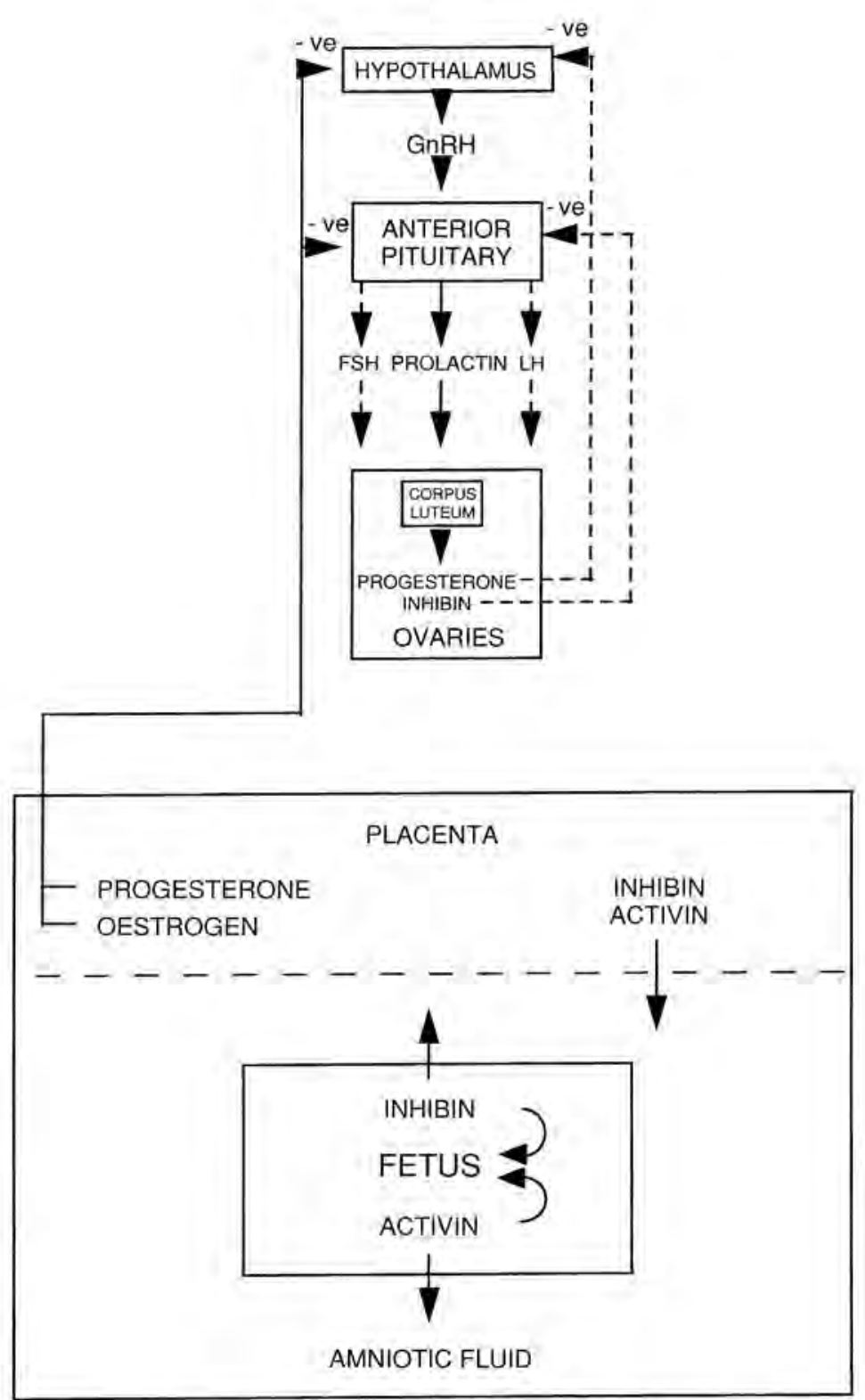

Fig. 2. Negative feedback mechanisms controlling maternal pituitary gonadotrophin and prolactin secretion in late pregnancy in ewes. It is proposed that progesterone and oestrogen, secreted primarily from the placenta of pregnant ewes, are responsible for inhibition of pituitary LH and FSH release and stimulation of prolactin release. In contrast to the oestrous cycle, relatively little inhibin is released from the ovary during pregnancy. Inhibin and activin produced by the placenta and fetus during pregnancy are not released into the maternal compartment but may have local effects on the fetus.

in the embryo and syncytiotrophoblast of the placenta at this time, whereas follistatin is localized in the embryonic neuronal system and the uterine myometrium (Roberts et al., 1991; Roberts, 1993). Such localization provides indirect evidence for the involvement of these peptides in embryonic 
growth and differentiation, although similar studies have not yet been undertaken in ruminants. Furthermore, the results of homologous recombination studies in mouse embryonic stem cells to create mouse strains carrying mutations in the genes encoding activin, inhibin and follistatin have been only partly successful in demonstrating their potential actions in embryos (Matzuk et al, I992, 1994; Vassalli et al, 1994).

\section{Fetal Development}

In a series of studies on the ontogeny of inhibin, activin and follistatin in ovine and bovine fetal tissues and fluids, we have demonstrated that both immunoactive and bioactive inhibin is present in the fetal testes throughout gestation with concentrations increasing to a maximum at approximately 130 days of gestation in sheep and between 210 days and term in cows (Torney et al, 1990, 1992; Wongprasartsuk et al., 1994). The increased concentrations of immunoactive versus bioactive inhibin concentrations observed in these tissues indicates that $\alpha$ subunit products of inhibin, which are immunoactive but do not suppress FSH production in the bioassay (Torney et al., 1992), predominate in the fetal testes of these species. An alternative explanation is that follistatin, concentrations of which reach a maximum in the ovine testes at between day 75 and day 95 of gestation (Wongprasartsuk et al., 1994), but which is present in testicular extracts at all stages of gestation, may inhibit biological but not immunological activity. Both bovine and ovine fetal ovaries also contain significant concentrations of inhibin during gestation but concentrations of immunoactive inhibin are lower than those observed in the testes at all stages of gestation studied.

The physiological significance of high concentrations of inhibin in the fetal gonads is not clear at present. In sheep, the pattern of inhibin concentrations in fetal testes is inversely proportional to that of testosterone (M. Goodman, D. M, de Kretser, J. McFarlane and G. Jenkin, unpublished). Whether this is a direct effect of inhibin within the testes, or whether a change in FSH-induced testosterone production is involved is not clear. The ovine fetal testes will certainly produce inhibin in response to FSH which, in turn, inhibits testosterone synthesis (Albers et al, 1989a). Furthermore, inhibin-rich pig follicular fluid can suppress FSH secretion by the pituitary in late gestation (Albers et al. 1989b). We demonstrated that inhibin concentrations are high in fetal plasma in late gestation, and that concentrations in the plasma of male fetuses are significantly higher than those in female fetuses (Wongprasartsuk et al., 1991). The pattern of inhibin secretion into the circulation bears an inverse relationship to circulating $\mathrm{FSH}$, in which concentrations in female fetuses are significantly higher than those observed in male fetuses in mid-gestation, with concentrations decreasing in both sexes before term (Sklar et al., 1981). The inverse relationship between circulating inhibin and FSH concentrations has been re-examined by Phillips et al. (1992), who demonstrated differences in bioactive versus immunoactive FSH. Although female fetuses have significantly higher concentrations of both bioactive and immunoactive FSH than do male fetuses in the circulation in late gestation, in contrast to immunoactive FSH, bioactive FSH does not decline towards term in either of the sexes. Phillips et al. (1992) also demonstrated that the plasma concentrations of inhibin were negatively correlated with those of immunoactive, but not bioactive, FSH in female fetal plasma but were not correlated with either form of FSH in male fetal plasma. This data, taken together with our observations of gonadal and circulating inhibin concentrations in the fetus, indicate feedback mechanisms between the gonads and the pituitary or hypothalamus may be active in the fetus in late gestation in a similar way to that in adults with high concentrations of inhibin in late gestation opposing FSH release by the pituitary. However, the role of inhibin versus that of circulating steroid concentrations may be different because in adults FSH secretion in female fetuses is relatively unopposed despite high concentrations of circulating steroid hormones (Nathanielsz et al., 1982), whereas in male fetuses, unlike in adults, the major negative feedback effect is likely to be due to inhibin and not testosterone, since testis and circulating concentrations of testosterone in the late gestation male fetus are low (Yu et al., 1983) and do not significantly decrease on castration, whereas FSH concentrations are high after castration in male but not in female fetuses (Mesiano et al., 1991, and see Fig. 3).

Although we have demonstrated that inhibin is present in fetal tissues other than the gonads, such as the adrenals and placenta (Wongprasartsuk et al, 1994), the major source of circulating inhibin in male 
FEMALE

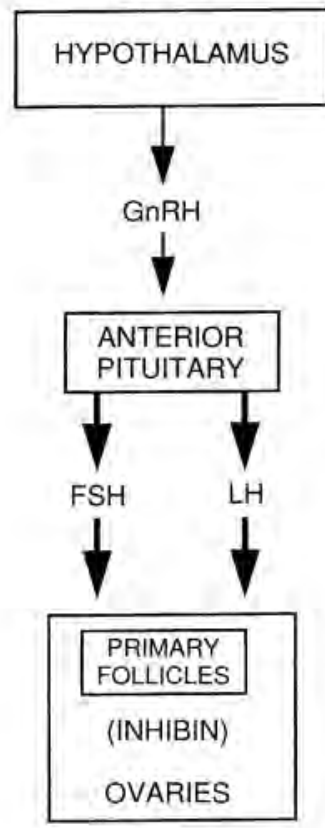

MALE

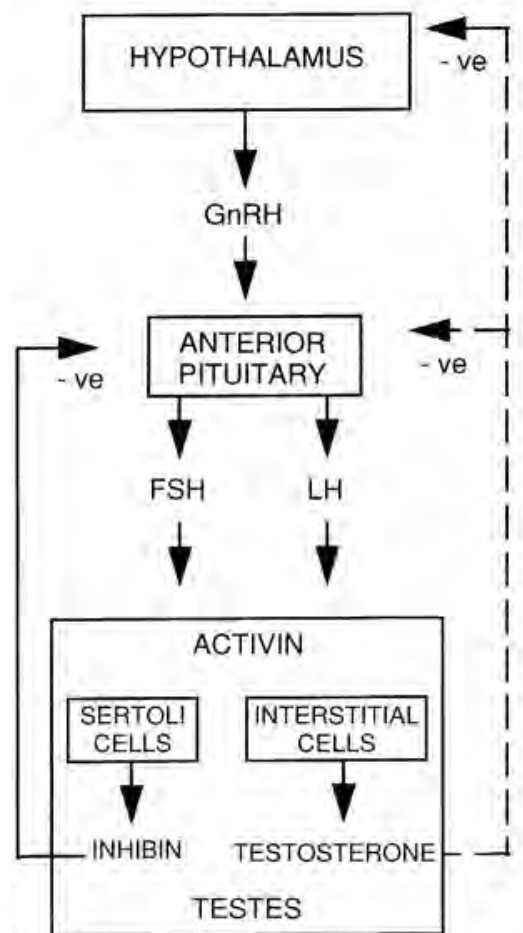

Fig. 3. Negative feedback mechanisms controlling fetal pituitary gonadotrophin secretion during late pregnancy in sheep. Secretion of pituitary gonadotrophins in the female fetus is relatively unopposed in late gestation, while secretion of gonadotrophins in the male fetus may be under the influence of inhibin produced by the fetal testes. Testosterone does not appear to play a major role in the control of hypothalamic or pituitary gonadotrophin secretion in the late gestation male fetus.

fetuses was demonstrated to be the gonads. Castration of male fetuses in late gestation leads to a precipitous decrease in circulating inhibin with concentrations reaching basal values within $12 \mathrm{~h}$ after castration. Analysis of decay curves of inhibin concentrations after castration indicates that inhibin has a half-life of approximately $3.5 \mathrm{~h}$ in fetal plasma (Jenkin et al., 1993). As determination of arterio-venous differences across the placenta indicates that inhibin is not secreted into the maternal plasma a $_{f}$ it is not known whether inhibin is metabolized within the fetus or is secreted either via the placenta or the fluids surrounding the fetus (allantoic and amniotic). A study of the concentrations of immunoactive inhibin in ovine amniotic fluid throughout gestation shows a similar pattern to that observed in the fetal gonads, with concentrations in amniotic fluid from male fetuses greatly exceeding those from female fetuses in late gestation and with maximum concentrations being observed at approximately 120 days of gestation (Fig. 4, Wongprasartsuk et al., 1994). Concentrations of inhibin in amniotic fluid decreased only slightly after castration of male fetuses and remained high throughout the remainder of gestation. Subsequent experiments indicate that either a source other than the fetal gonads is partly responsible for the high concentrations of inhibin, and/or that inhibin is not rapidly metabolized in late gestation in this compartment. The high concentrations of follistatin, which have the potential to bind inhibin, observed in amniotic fluid of both male and female fetuses in late gestation (Wongprasartsuk et al., 1994) may account for this potential lack of metabolism.

When amniotic fluid samples from either male or female fetuses were subjected to bioassay, FSH concentrations in the rat pituitary cell bioassay were significantly stimulated at all gestational ages studied. It was subsequently demonstrated that this stimulation of FSH was due to the presence of high 

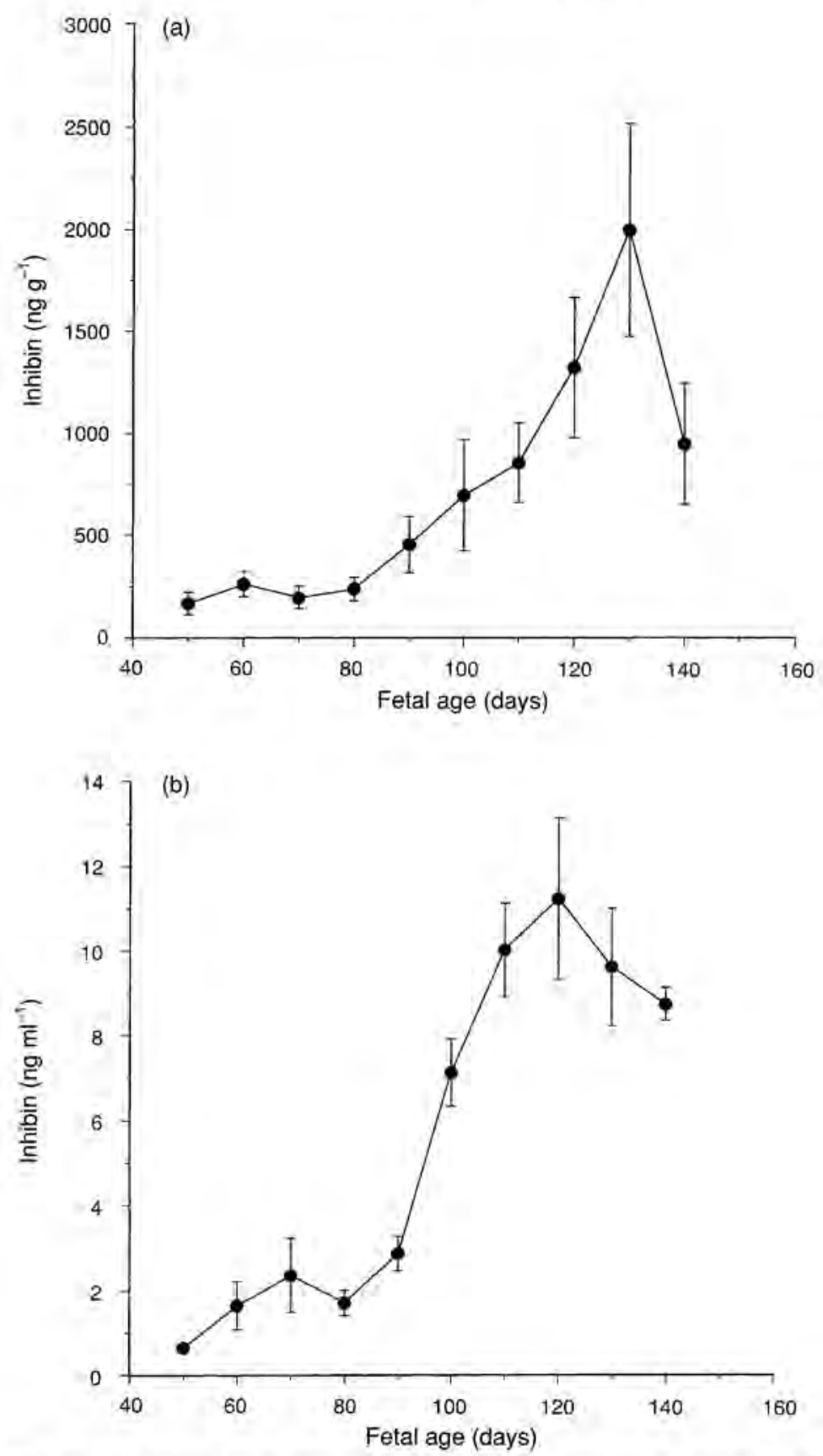

Fig. 4. Concentrations of immunoactive intribin determined in (a) testes of fetus and (b) amniotic fluid of male fetuses during gestation in ewes. Values are means \pm SEM of between three and 12 samples at each gestational age, Redrawn from Wongprasartsuk et al. (1994) by permission of the Journal of Endocrinology Ltd.

concentrations of bioactive activin in the amniotic fluid samples (de Kretser et al., 1994) which far exceeded those of follistatin during most of gestation. Activin from sheep amniotic fluid has 
subsequently been isolated and purified and the amino-terminal amino acid sequence shown to be identical to the known sequence of sheep activin A (de Kretser et al., 1994).

Although the major source of inhibin, activin and follistatin is likely to be the fetus, the fetal membranes and placenta cannot be excluded as a potential source of these proteins in amniotic fluid. It is important that further studies on the source of, and possible role of, these multipotent proteins in the fetus and fetal fluid compartment surrounding the fetus are undertaken.

\section{Conclusions}

Initial studies on the role of inhibin and activin in adult ruminants have focused on their feedback regulatory function in nonpregnant animals, as a regulator of follicular recruitment and in the control of ovulation rate. Follistatin has been promoted as a factor responsible for neutralizing activin in the circulation and the ability of specific molecular forms of follistatin to bind to heparan sulfate proteoglycans on the cell surface has led to the suggestion that it may present activin to its cell surface receptor.

The maternal plasma of ruminants contains basal concentrations of inhibin throughout gestation. Furthermore, unlike during the oestrous cycle, circulating inhibin concentrations in maternal plasma are not inversely related to circulating gonadotrophin concentrations, or to pituitary responsiveness to $\mathrm{GnRH}$, which are all minimal in late gestation. It is unlikely, therefore, that inhibin has a negative feedback role on gonadotrophins in the mother during gestation.

The cloning of inhibin and activin has led to the observation that the $\beta$ subunit exhibits a high degree of similarity with a number of potent growth promoting and differentiation factors. Studies in rats have demonstrated that inhibin, activin and follistatin are expressed in embryonic and fetal tissues, as well as in the placenta, and that activin affects the growth and differentiation of a number of cell types in a variety of species, including mesoderm induction, regulation of anterior-posterior polarity and induction of the body axis. Follistatin antagonizes many of these biological actions. In ruminants, immunoactive and bioactive inhibin and follistatin are present in the fetal testes, ovaries, adrenals and placenta throughout gestation. Fetal testicular inhibin concentrations increase markedly from mid-gestation, resulting in high concentrations of circulating inhibin in male fetal plasma in late gestation which rapidly decrease to basal values after castration. Although the stimulus for these high concentrations of inhibin in the male fetus is not known, they are associated with a decrease in testicular testosterone and a decrease in circulating FSH concentrations suggesting that, as in adults, inhibin may be directly or indirectly involved in the regulation of testicular androgen and pituitary FSH secretion during late gestation.

Inhibin concentrations in ovine amniotic fluid, in fetuses of both sexes, increase during gestation, and concentrations in male fetuses are greater than those in female fetuses. The fetal gonads account for most of the inhibin observed in amniotic fluid and it is secreted into this compartment from both urine and tracheal fluid. However, an extra-gonadal source, probably the fetal membranes, also contributes to inhibin concentrations in amniotic fluid in late gestation. Follistatin is detectable in amniotic fluid but its concentration does not appear to alter during gestation, nor is there a significant difference between the sexes. Recent studies have demonstrated that concentrations of activin are much greater than those of follistatin in amniotic fluid for most of gestation. Activin has been purified from amniotic fluid and sequenced and shown to be identical to the known sequence of ovine activin $A$.

The role of these potentially potent regulatory proteins in this fetal fluid compartment is not known. However, it is possible that they constitute an inactive reservoir of hormone secreted from the fetus or that they are partly produced and secreted from the fetal tissues surrounding the amniotic fluid. The regulatory role, if any, of these potentially potent growth and differentiation factors in the fetus and amniotic fluid has yet to be established.

Research described in this review was undertaken under the auspices of $\mathrm{NH}$ and MRC funding to the authors. 


\section{References}

Albers N, Bettendorf M, Hart CS, Kaplan SI. and Grumbach MM (1989a) Hormone ontogeny in the ovine fetus. XXIII. Pulsatile administration of follicle-stimulating hormone stimulates inhibin production and decreases testosterone synthesis in the ovine fetal gonad Endocrinology 124 3089-3094

Albers N, Hart CS, Kaplan SL and Grumbach MM (1989b) Hormone ontogeny in the ovine fetus. XXIV Porcine follicular fluid "inhribins" selectively suppress plasma follicle stimulating hormone in the ovine fetus Endocrinology 125 675-678

Attisano L. Wrana IL. Cheifetz S and Massagué J (1992) Novel activin receptors: distinct genes and alternative mRNA splicing generate a repertoire of serine/thronine kinase receptors Cell 68 97-108

Bilezikjian LM, Corrigan AZ and Vale WW (1993) Activin-B, inhibin-B and follistatin as autocrine/paracrine factors of the rat anterior pituitary. Frontiers in Endocrinology 3, Inlibin and inlibin-related proteins pp 81-99. Ares-Serono Symposia Publications, Rome

Challis JRG (1971) Sharp increase in free circulating oestrogens immediately before parturition in sheep Nature $\mathbf{2 2 9}$ 208

Chamley WA, Findlay JK, Jonas H, Cumming IA and Goding JR (1974a) Elfect of pregnancy on the FSH response to synthetic gonadotrophin-releasing hormone in ewes Journal of Reproduction and Ferfility 37 109-112

Chamley WA. Findlay JK, Cumming IA, Buckmaster JM and Goding JR (1974b) Effect of pregnancy on the LH response to synthetic gonadotrophin releasing hormone in the ewe Endocrinology 94 291-293

Chamley WA, Jonas JA and Parr RA (1976) Control of LH, FSH and growth hormone in the pituitaries of pregnant and anestrous sheep Endocrinology 98 1435-1438

de Kretser DM and Robertson DM (1989) The isolation and physiology of inhibin and related proteins Biology of Reproduction 40 33-47

de Kretser DM, Foulds LM, Hancock M, McFarlane J, Goss N and Jenkin G (1994) The isolation of activin from ovine amniotic fluid Exdocrinology $134 \quad 1231-1237$

De Paolo LV, Shimonaka M, Schwall RH and Ling N (1991) In vivo comparison of the follide-stimulating hormonesuppressing activity of follistatin and inhibin in ovariectomised rats Endocrinology 128 668-674

Findlay JK (1993) An update on the roles of inhibin, activin, and follistatin as a local regulator of folliculogenesis Biology of Reproduction 48 15-23

Findlay JK, Doughton BW and Russell DC (1991) peripheral concentrations of immunoreactive inhibin during pregnancy and parturition in the ewe Reproduction, Fertility and Development 3 543-549

Forage RG, Ring JM, Brown PW, Mclnerney BV, Cobon GS, Gregson RP, Robertson DM, Morgan FJ, Hearn MTW, Findlay JK, Wettenhall REH, Burger HG and de Kretser DM (1986) Cloning and sequence analysis of CDNA species coding for the two subunits of inhibin from bovine follicular fluid Proceedings of the National Academy of Sciences USA 83 3091-3095

Huylebroeck D, Verschueren K and De Waele P (1993) Activins: multipotent regulators of cellular function, differentiation and development. Frontiers in Endocrinology 3, Inhibin and inhibin related proteins pp 272-287. Ares-Serono Symposia Publications, Rome

Jenkin G (1975) Pituitary Function in the Sheep: Factors Affecting the Synthesis and Release of Luleinizing hormone. PhD Thesis, University of Cambridge

Jenkin G and Heap RB (1974) The lack of response of the sheep pituitary to luteinizing hormone releasing hormone stimulation in gestation and early lactation: the probable role of progesterone Journal of Endocrinology 61 xii-xiii

Jenkin G, Heap RB and Symons DBA (1977) Pituitary responsiveness to synthetic LHRH and pituitary LH content at various reproductive stages in the sheep Journal of Reproduction and Fertility 49 207-214

Jenkin G, Miller S, Young R, Wongprasartsuk $S$ and de Kretser DM (1993) Source of inhibin in amniotic fluid and fetal plasma in the sheep Journal of Reproduction and Fertility Abstract Series 11 Abstract 83

Ling N, Ying S-Y, Ueno N, Esch F, Denoroy $\mathrm{L}$ and Guillemin R (I985) Isolation and partial characterisation of $\mathrm{M}_{1} 32000$ protein with inhibin activity from porcine follicular fluid Proceedings of the National Academy of Sciences USA $\mathbf{8 2}$ $7217-7221$

Mason AJ, Hayflick JS, Ling N, Esch F, Ueno N, Ying S-Y, Guillemin R, Niell H and Seeburg PH (1985) Complimentary DNA sequences of ovarian follicular fluid inhibin show precursor structure and homology with transforming growth factor- $\beta$ Nature $\mathbf{3 1 8} 659-663$

Massague J (1990) The transforming growth factor- $\beta$ family Anumal Review of Cell Biology 6 597-641

Matthews LS and Vale WW (1991) Expression cloning of an activin receptor, a predicted transmembrane serine kinase Cell 65 973-982

Matzuk MM Finegold MJ. Su J-GJ, Hsueh AJW and Bradley A (1992) $\alpha$-Inhibin is a tumour-suppressor gene with gonadal specificity in mice Nature $360313-319$

Matzuk MM, Kumar TR, Lu H, Towns R and Bradley A (1994) Functional analysis of activins during mammalian development US Endocrine Sociely Abstracts 76, 1650

Mesiano S, Hart CS, Heyer BW, Kaplan SL. and Grumbach MM (1991) Hormone ontogeny in the ovine fetus XXVI: a sex difference in the effect of castration on the hypothalamicpituitary-gonadotropin unit in the ovine fetus Endocrinology $1293073-3079$

Michel U, Farnworth P and Findlay JK (1993) Follistatins: more than follicle stimulating hormone suppressing proteins Molecular and Cellular Endocrinology 91 1-11

Mitrani E, Zir T, Thomson G, Shirroni Y, Melton DA and Bril A (1990) Activin can induce the formation of axial structures and is expressed in the hypoblast of the ehick Cell 63 495-501

Nakamura T, Takio K, Eto Y, Shibai H, Titani K and Sugino H (1990) Activin-binding protein from rat ovary is follistatin Science $247 \quad 836-838$

Nakamura T, Sugino K, Titani K and Sugino H (1991) Follistatin, an activin binding protein, associates with haparan sulphate chains on follicular granulosa cells Joumal of Biological Chemistry 266 19432-19437

Nathanielsz PW, Elsner C, Magyar D, Fridshal D, Freeman A and Buster JE (1982) Time trend analysis of plasma unconjugated and sulfoconjugated estrone and $3 \beta-\Delta^{5}$-steroids in 
fetal and matemal sheep plasma in relation to spontaneous parturition at term Endocrinology 110 1402-1407

Phillips DJ, Smith PR, Heath DA, Condell LA and McNatty KP (1992) Bioactive and immunoreactive FSH and immunoreactive inhibin concentrations in the ovine fetus Journal of Endocrinology 134 287-295

Roberts VJ (1993) Inhibin/activin system in post-implantation rat embryogenesis. Frantiers in Endocrinology 3, Inhibin and inkibin related proteins pp 290-300. Ares-Serono Symposia Publications, Rome

Roberts VJ. Sawchenko PE and Vale W (1991) Expression of inhibin/activin subunit mRNAs during rat embryogenesis Endocrinology $128 \quad 3122-3129$

Robertson DM, Foulds LM, Leversha L, Morgan FJ, Hearn MTW, Burger HG, Wettenhall REH and de Kretser DM (1985) Isolation of inhibin from bovine follicular fluid Biochemical and Biophysical Research Communications 126 220-226

Robertson DM, Klein R, de Vos FL, McLachlan RI, Wettenhall REH, Hearn MTW, Burger HG and de Kretser DM (1987) The isolation of polypeptides with FSH suppressing activity from bovine follicular fluid which are structurally different to inhibin Biochemical and Biophysical Research Communications 149 744-749

Robertson DM, Tsonis CG, Mclachlan RI, Handelsman DJ, Leask R, Baird DT, McNeilly AS, Hayward S, Healy DL, Findlay JK, Burger HG and de Kretser DM (1988) Comparison of inhibin immunological and in vitro biological activities in human serum Joumal of Clinical Endocrinology and Metabolism 67 438-443

Robertson DM, Farnworth PG, Clarke L, Jacobsen J, Cahir NF, Burger HG and de Kretser DM (1990) Effects of bovine $35 \mathrm{kDa}$ FSH-suppressing protein on FSH and $\mathrm{LH}$ in rat pituitary cells in vitro: comparison with $31 \mathrm{kDa}$ inhibin Journal of Endocrinology 124 417-423

Shimonaka M. Inouye S. Shimasaki S and Ling N (1991) Follistatin binds to both activin and inhibin through the common beta-subunit Endocrinology $128 \quad 3313-3315$

Sklar CA, Mueller PL, Gluckman PD, Kaplan SL, Rudolph AM and Grumbach MM (1981) Hormone ontogeny in the ovine fetus. VII. Circulating LH and FSH in mid-and lategestation Endocrinology 108 874-880

Taya K, Komura H, Watanabe G and Sasamoto S (1989) Peripheral blood levels of immunoreactive inhibin during pseudopregnancy. pregnancy and lactation in the rat Journal of Endocrinology 121 545-552

Tilbrook AJ, de Kretser DM and Clarke IJ (1992) A role for inhibin in the regulation of the secretion of follicle stimulating hormone in male domestic animals Domestic Animal Endocrinology 9 243-260
Tilbrook AJ, de Kretser DM and Clarke IJ (199.3) Human recombinant inhibin $\mathrm{A}$ and testosterone act directly at the pituitary to suppress plasma concentrations of FSH in castrated rams Joumal of Endocrinology 138 181-189

Torney AH, Robertson DM, Hodgson YV and de Kretser DM (1990) In vitro bioactive and immunoactive inhibin concentrations in bovine fetal ovaries and testes throughout gestation Endocrinology 127 2938-2946

Torney AH, Robertson DM and de Kretser DM (1992) Characterisation of inhibin and related proteins in bovine fetal testicular and ovarian extracts: evidence for the presence of inhibin subunit products and FSH-suppressing protein Journal of Endocrinology 133 111-120

Ueno N, Ling N, Ying SY, Esch, F, Shimasaki S and Guillemin R (1987) Isolation and partial characterisation of follistatin: a single-chain $M_{\mathrm{r}} 35000$ monomeric protein that inhibits the release of follicle stimulatory hormone Proceedings of the National Academy of Sciences UISA 84 8282-8286

Vassalli A, Matzuk MM, Gardner HA, Lee KF and Jaenisch R (1994) Activin/inhibin $\beta$ subunit gene disruption leads to defects in eyelid development and female reproduction Genes and Development 8 414-427

Wongprasartsuk S, Wlodek ME, Jenkin G and de Kretser DM (1991) Fetal and matemal immunoactive inhibin concentrations in the ewe during pregnancy Procedings of the Endocrine Sociefy of Australia 3422

Wongprasartsuk S, Jenkin G, McFarlane JR, Goodman M and de Kretser DM (1994) Inhibin and follistatin concentrations in fetal tissues and fluids during gestation in sheep: evidence for activin in amniotic fuid Journal of Endocrinol. ogy 141 219-229

Wright PJ, Jenkin G, Heap RB and Walters DE (1978) Pituitary responsiveness to LH-RH and TRH and the effects of progesterone or progesterone and oestradiol treatment in anoestrous sheep Journal of Reproduction and Fertility 52 34.3-348

Wright PJ. Jenkin G and Heap RB (1981) Prolactin and LH release in response to $\mathrm{LH}-\mathrm{RH}$ and TRH in ewes during dicestrus, pregnancy and post-partum Journal of Reproduc: Hion and Ferfility 62 447-453

Yohkaichiya T, O'Connor A and de Kretser DM (1991) Circulating immunoreactive inhibin, gonadotrophin, and prolactin levels during pregnancy, lactation and postweaning estrous cycle in the rat Biology of Reproduction 44 b-12

Yu HK, Cabalum T, Jansen AM, Buster JE and Nathanielsz PW (1983) Androstenedione, testosterone and estradiol concentrations in fetal and maternal plasma in late pregnancy in the sheep Endocrinology 113 2216-2220 